University of Nebraska - Lincoln

DigitalCommons@University of Nebraska - Lincoln

\title{
Population Genetic Structure in Migratory Sandhill Cranes and the Role of Pleistocene Glaciations
}

\author{
Kenneth L. Jones \\ University of Illinois at Chicago \\ Gary L. Krapu \\ USGS Northern Prairie Wildlife Research Center, gkrapu@usgs.gov \\ David A. Brandt \\ USGS Northern Prairie Wildlife Research Center, dbrandt@usgs.gov \\ Mary V. Ashley \\ University of Illinois at Chicago, ashley@uic.edu
}

Follow this and additional works at: https://digitalcommons.unl.edu/usgsnpwrc

Part of the Other International and Area Studies Commons

Jones, Kenneth L.; Krapu, Gary L.; Brandt, David A.; and Ashley, Mary V., "Population Genetic Structure in Migratory Sandhill Cranes and the Role of Pleistocene Glaciations" (2005). USGS Northern Prairie Wildlife Research Center. 55.

https://digitalcommons.unl.edu/usgsnpwrc/55

This Article is brought to you for free and open access by the US Geological Survey at DigitalCommons@University of Nebraska - Lincoln. It has been accepted for inclusion in USGS Northern Prairie Wildlife Research Center by an authorized administrator of DigitalCommons@University of Nebraska - Lincoln. 


\title{
Population genetic structure in migratory sandhill cranes and the role of Pleistocene glaciations
}

\author{
KENNETH L. JONES, ${ }^{*}$ GARY L. KRAPU,+DAVID A. BRANDT+ and MARY V. ASHLEY* \\ *University of Illinois at Chicago, Department of Biological Sciences (M/C 066), Chicago, Illinois 60607-7060, +USGS, Northern \\ Prairie Wildlife Research Center, Jamestown, North Dakota 58401
}

\begin{abstract}
Previous studies of migratory sandhill cranes (Grus canadensis) have made significant progress explaining evolution of this group at the species scale, but have been unsuccessful in explaining the geographically partitioned variation in morphology seen on the population scale. The objectives of this study were to assess the population structure and gene flow patterns among migratory sandhill cranes using microsatellite DNA genotypes and mitochondrial DNA haplotypes of a large sample of individuals across three populations. In particular, we were interested in evaluating the roles of Pleistocene glaciation events and postglaciation gene flow in shaping the present-day population structure. Our results indicate substantial gene flow across regions of the Midcontinental population that are geographically adjacent, suggesting that gene flow for most of the region follows an isolationby-distance model. Male-mediated gene flow and strong female philopatry may explain the differing patterns of nuclear and mitochondrial variation. Taken in context with precise geographical information on breeding locations, the morphologic and microsatellite DNA variation shows a gradation from the Arctic-nesting subspecies G. c. canadensis to the nonArctic subspecies G. c. tabida. Analogous to other Arctic-nesting birds, it is probable that the population structure seen in Midcontinental sandhill cranes reflects the result of postglacial secondary contact. Our data suggest that subspecies of migratory sandhills experience significant gene flow and therefore do not represent distinct and independent genetic entities.

Keywords: Gruidae, isolation by distance, microsatellite DNA, Pleistocene glaciation, population genetics, satellite telemetry
\end{abstract}

Received 26 September 2004; revision received 22 March 2005; accepted 12 April 2005

\section{Introduction}

Pleistocene glacial influences on Arctic bird populations

There is a growing body of knowledge regarding the migration and population genetic patterns of Arctic-nesting birds. First described for waterfowl, glaciations during the Pleistocene are thought to have been major factor in the differentiation of many Arctic-nesting birds (Ploeger 1968). Modern DNA methodologies allow researchers to assess current and historical patterns of gene flow in an effort to find explanations for the phylogeographical distributions seen today (Rogers 1995; Webster et al. 2002). Using

Correspondence: Kenneth L. Jones, Kansas State University, Division of Biology, 264 Chalmers Hall, Manhattan, Kansas 66506, USA. Fax: 1801457 2897; E-mail: KenJones@ksu.edu mitochondrial DNA (mtDNA) sequencing, significant divergences have been discovered in many taxa previously thought to be closely related (Klicka \& Zink 1997, 1999; Avise \& Walker 1998; Avise et al. 1998; citations therein). Although there is much debate on the accuracy of using DNA to estimate divergence time (Klicka \& Zink 1997), recent research indicates that Pleistocene glaciations have been a major influence on the divergences seen in many bird species (Avise \& Walker 1998; Avise et al. 1998; Klicka \& Zink 1999).

Current theories of speciation by glaciation contend that widespread ancestral populations were split by Pleistocene glaciations and subsequently evolved significant genetic differences among their allopatric populations (Avise \& Walker 1998). However, not all populations ancestrally split by glaciation progressed to speciation. The results of postglaciation secondary contact of previously allopatric 
populations may provide insight into the progression of the speciation process (Barton \& Hewitt 1985; Hewitt 1996). During glacial isolation, associated demographic processes (such as reduced population sizes) may result in uneven partitioning of existing genetic variation or the occurrence of new mutations in some populations. If these processes result in differentiated mitochondrial haplotype distributions and allele frequencies at nuclear loci, the outcome of postglaciation contact can be assessed through population genetic analysis (Ball \& Avise 1992; Rogers 1995; Hewitt 1996). In many Arctic birds, researchers have used genetic markers to measure the outcomes of such secondary contact events. In some bird species [e.g. rock ptarmigan, Lagopus mutus (Holder et al. 1999), dunlins, Calidris alpina (Wenink et al. 1996), Brewer's sparrow, Spizella breweri (Klicka \& Zink 1997)] genetic and morphometric characteristics remain geographically localized, suggesting that two taxa were formed. Alternatively, with species like the snow geese (Chen caerulescens), genetic analysis shows that high gene flow has caused the distinct mtDNA haplotypes produced by Pleistocene glaciations to be shared across many populations (Avise et al. 1992). In this case, the morphological and nuclear diversity shows a gradient of variation across their range. Intermediate to these examples are species such as Canada geese (Branta canadensis) in which a combination of natal philopatry and male-mediated gene flow produce a population where mtDNA and morphological variation may be localized, but nuclear variation has a more clinal distribution (Van Wagner \& Baker 1990). Although sandhill cranes (Grus canadensis) are reported to have strong natal philopatry (Walkinshaw 1949; Littlefield 1968; Drewien 1974; Littlefield \& Ivey 1995; Nesbitt et al. 2002), it is not known whether the geographical partitioning of two major mtDNA clades, reported to be a result of Pleistocene glaciation (Rhymer et al. 2001), has been maintained by female philopatry, and whether nuclear variation also reflects the effects of glaciation. Studies of nuclear variation will help assess reinforcement or the progression of hybridization in post-Pleistocene sandhill populations, and provide evidence for gender-biased gene flow should it exist.

\section{Sandhill crane population history}

The sandhill crane is the most abundant of the 15 described species of cranes (Meine \& Archibald 1996). The world's population of more than 500000 birds is distributed widely across North America and extends to northeastern Siberia and as far south as Cuba (Fig. 1, Walkinshaw 1973; Johnsgard 1983; Meine \& Archibald 1996). The taxonomy of sandhill cranes, originally derived through morphometric and geographical distinctions, has been the subject of many studies. Within this species, a detailed history chronicles the designation of as many as eight populations and six subspecies (Fig. 1, Table 1). In contrast to the type specimen collected from the Arctic region of North America (lesser sandhill, Grus canadensis canadensis), a nonmigratory population of sandhill cranes was discovered in Florida and designated by Meyer (1794) as Grus pratensis. The Florida population was later recognized as a subspecies of sandhill crane (Florida sandhill, Grus canadensis pratensis) (Peters 1925). Subsequently the Cuban sandhill (Grus canadensis nesiotes) was identified in the mid-19th century by Poey (1854) and then named as a subspecies by Bangs \& Zappey (1905). Although subspecies to this point were primarily distinguished on the basis of geography and migratory habit, subsequent changes to sandhill taxonomy used morphology to differentiate subspecies. An additional migratory subspecies, greater sandhill (Grus canadensis tabida) from central North America was named by Peters (1925) due to its larger body size. Walkinshaw (1949) defined a subset of birds geographically and morphologically intermediate to the northern G. c. canadensis and southern G. c. tabida breeding in central Canada. These birds were subsequently named the Canadian sandhill (Grus canadensis rowani) (Walkinshaw 1965; Aldrich 1979). A final nonmigratory subspecies (Mississippi sandhill, Grus canadensis pulla) was named by Aldrich (1972) based on recent population restrictions and minor plumage differences.

There are currently five major populations of migratory sandhill cranes (Fig. 1, Table 1). The largest of these populations, the Midcontinental population (MCP), breeds in the northern regions of North America and Siberia and contains all three migratory subspecies (Johnson \& Stewart 1973). The birds of the MCP migrate great distances annually to overwinter in areas of the Texas Plains, Texas Gulf Coast, New Mexico, Arizona, and northern Mexico (Fig. 1) (Tacha et al. 1984; Drewien et al. 1996; Krapu \& Brandt 2002). Like the MCP, cranes using the flyway in states and provinces along the Pacific coast are represented by all three migratory subspecies. The Pacific Flyway population (PFP) breeds in Alaska primarily from the Alaskan Peninsula east to the Kenai Peninsula and upper Cook Inlet (Petrula \& Rothe 2002, unpublished); however a segment of this population has recently been identified on islands off British Columbia and far into the southeastern Alaskan coasts (Ivey et al. in press). An adjacent population, the Central Valley population (CVP), contains only G. c. tabida and breeds in portions of British Columbia, Washington, Oregon, Nevada, and California (Pacific Flyway Council 1983; Pogson \& Lindstedt 1991). Collectively, the sandhill cranes from the CVP and PFP converge on a common wintering ground in the Central Valley of northern California (Pogson \& Lindstedt 1991; Petrula \& Rothe 2002, unpublished). In addition to these northern populations, the Eastern Flyway population (EFP) breeds in the Great Lakes region of the USA and in southern Canada east of Hudson Bay (Meine \& Archibald 1996) and winters in areas of southern Georgia and central Florida (Walkinshaw 1973; 


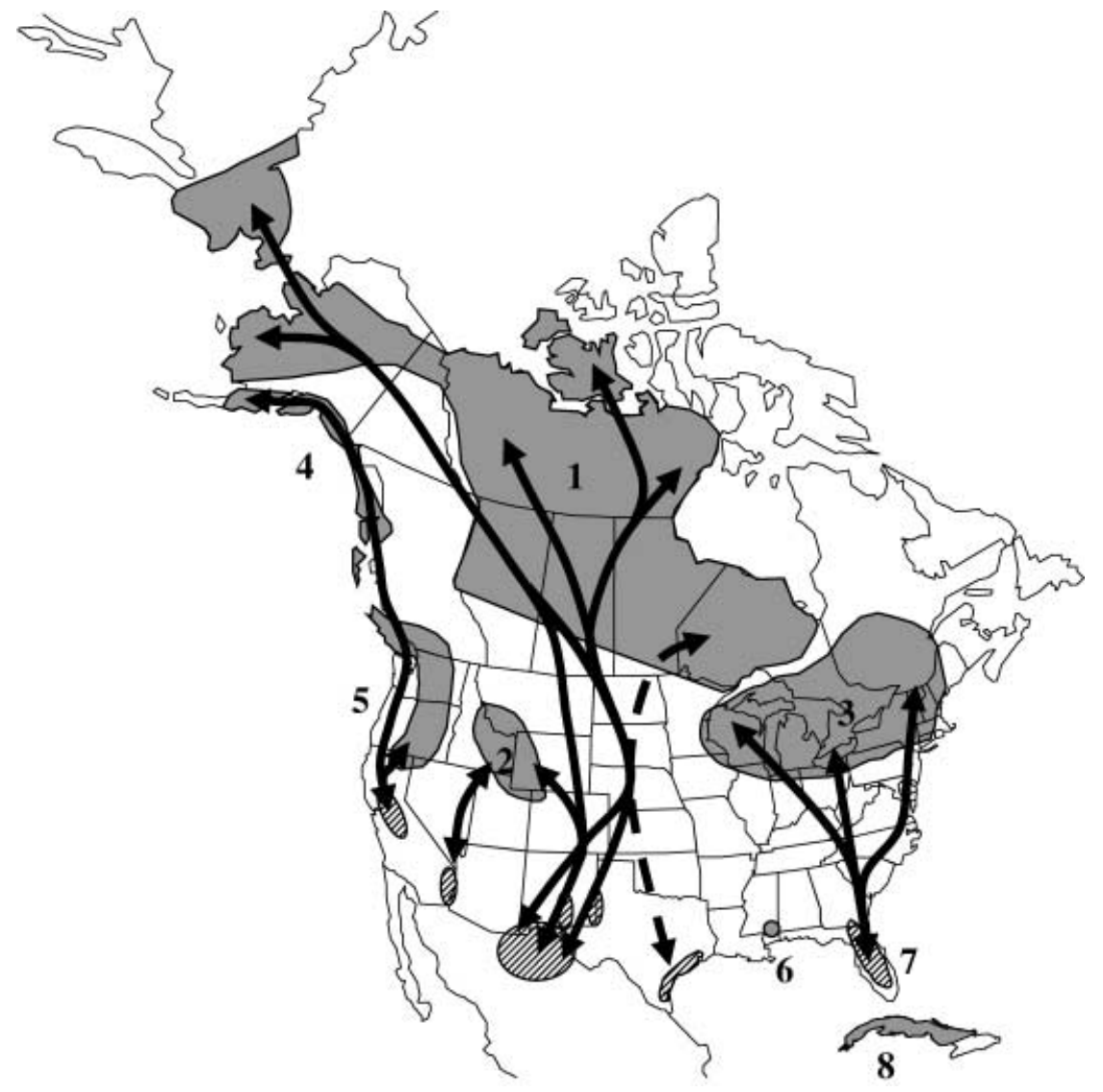

Fig. 1 Migration and range map for the sandhill crane. Breeding (grey) and overwintering (hashed) ranges, as well as, migratory paths are shown (adapted from Johnsgard 1983; Meine \& Archibald 1996; Krapu \& Brandt 2002). A key to population designation is given in Table 1.

Table 1 Key to sandhill crane populations

\begin{tabular}{|c|c|c|c|}
\hline Population & Subspecies & Breeding location & Wintering location \\
\hline 1. Midcontinental population (MCP) & $\begin{array}{l}\text { G.c. canadensis, } \\
\text { G.c. rowani, } \\
\text { G.c.tabida }\end{array}$ & $\begin{array}{l}\text { Eastern Siberia, Alaska, central } \\
\text { Canada from the Canadian } \\
\text { Rockies to Hudson Bay, and Minnesota }\end{array}$ & $\begin{array}{l}\text { Texas Plains, New Mexico, Arizona, } \\
\text { Mexico, and Gulf Coast of Texas }\end{array}$ \\
\hline 2. Rocky Mountain population (RMP) & G. c. tabida & $\begin{array}{l}\text { Colorado, Idaho, Montana, } \\
\text { Utah, and Wyoming }\end{array}$ & New Mexico, Arizona, and Mexico \\
\hline 3. Eastern Flyway population (EFP) & G.c. tabida & $\begin{array}{l}\text { Great Lakes Region of the USA and } \\
\text { southeastern Canada }\end{array}$ & $\begin{array}{l}\text { Southern Georgia, and } \\
\text { central Florida }\end{array}$ \\
\hline 4. Pacific Flyway population (PFP) & $\begin{array}{l}\text { G.c. canadensis, } \\
\text { G.c. rowani }\end{array}$ & $\begin{array}{l}\text { Coastal regions of southern Alaska } \\
\text { and northern British Columbia }\end{array}$ & Central Valley of California \\
\hline 5. Central Valley population (CVP) & G. c. tabida & $\begin{array}{l}\text { British Columbia, Washington, } \\
\text { Oregon, Nevada, and California }\end{array}$ & Central Valley of California \\
\hline 6. Mississippi Sandhill population & G.c. pulla & $\begin{array}{l}\text { Mississippi Sandhill Crane } \\
\text { National Wildlife Refuge }\end{array}$ & Nonmigratory \\
\hline 7. Florida Sandhill population & G.c.pratensis & South-central Georgia and central Florida & Nonmigratory \\
\hline 8. Cuban Sandhill population & G.c. nesiotes & Mainland Cuba and the Isla de la Juventud & Nonmigratory \\
\hline
\end{tabular}

Lewis 1977). The last of the migratory populations, the Rocky Mountain population (RMP), contains only G.c. tab$i d a$ and breeds in the Rocky Mountain region of the USA from southern Idaho and Montana to northern Utah and
Colorado (Drewien et al. 1999). The eastern portion of RMP cranes migrate through Colorado where they encounter and subsequently overwinter with a portion of the migratory birds of the MCP (Drewien et al. 1999). 


\section{Genetic studies of migratory sandhill cranes}

There has been much debate in the literature on the validity of the taxonomic designations given to sandhill cranes (see Johnson \& Stewart 1973; Tacha 1981, 1988; Tacha et al. 1985; Rhymer et al. 2001; Glenn et al. 2002). Given that subspecific designations are solely derived through differences in morphology, plumage, and geography, subspecific designations may not reflect genetically distinct taxa. For example, decades after Oberholser (1921) first noted the geographical integration of G. c. canadensis and G. c. tabida within the MCP, Tacha et al. (1985) observed mixed pairs of small- and medium-sized birds, as well as pairs of small and large sized birds, providing the first evidence that mating potentially occurs between migratory subspecies. As assignments of sandhill cranes to subspecies is difficult due to overlapping morphological ranges (Johnson \& Stewart 1973; Gaines \& Warren 1984; Tacha et al. 1985), there have been five studies that attempt to describe the three migratory subspecies through genetic analysis. Gaines \& Warren (1984) presented evidence for a fixed allozyme allele difference between birds of the G. $c$. canadensis subspecies and those from southern Canada (i.e. G. c. rowani and G. c. tabida subspecies). In a follow-up study, Tacha et al. (1986) showed that this 'fixed' allozyme allele was present in $88 \%$ of G. c. tabida, $64 \%$ of G. c. rowani, and $18 \%$ of G. c. canadensis, thus indicating the possibility of greater gene flow between the subspecies than was previously thought. Recently, three studies were completed using mtDNA sequencing. Glenn et al. (2002) and Petersen et al. (2003) used the highly variable portion of the control region of the mitochondrial genome to assess variation in the MCP only, whereas Rhymer et al. (2001) used the entire control region to quantify variation among all but the Cuban subspecies. All three studies produced similar results. Within all the named subspecies, there seems to be only two evolutionary lineages: lineage I, which is comprised primarily of G. c. canadensis; and lineage II, which contains the remaining G. c. rowani, G. c. tabida, G.c. pratensis, G. c. pulla, and G. c. nesiotes subspecies (Rhymer et al. 2001). As lineages I and II are 5.3\% divergent, Rhymer et al. (2001), Glenn et al. (2002), and Petersen et al. (2003) concluded that only two of the three migratory subspecies were phylogenetically valid. A call to consolidate G. c. rowani and G.c. tabida was made. Although these three studies clarified the mtDNA variation of this species, sampling of nuclear variation has been limited. The specific objectives of this study were to quantify the population structure and/or gene flow between three of the major populations of migratory sandhill cranes using microsatellite DNA and to determine if nuclear variation in combination with mtDNA provides a more complete picture of the genetics of the MCP. The more general objectives were to compare patterns of mitochondrial and nuclear differentiation among migratory sandhill crane populations, and to use these patterns to infer population history and the possible role of Pleistocene glaciations in determining the present genetic structure of the species.

\section{Methods}

\section{DNA sampling}

A total of 191 blood samples were obtained from the following populations: Midcontinental population (91), obtained as part of USGS Northern Prairie Wildlife Research Center's studies to delineate the breeding grounds, migration routes, and wintering grounds of subspecies and subpopulations that form the Midcontinental population (Krapu \& Brandt 2002); the Rocky Mountain population (26), obtained from a study by the Colorado Division of Wildlife and USGS to examine the ecology of cranes that migrate through the San Luis Valley in Colorado (Gammonley \& Laubhan 2002); and the Eastern Flyway population (74), obtained from the International Crane Foundation's studies of cranes that breed in Wisconsin (Hayes et al. 2003). For all samples, whole blood was drawn and placed into a storage/ lysis buffer [0.1 м Tris, 0.1 м EDTA, 5\% SDS, 0.01 м NaCl; (Longmire et al. 1991)] for later extraction. DNA isolation from the lysate followed protocols for the Promega Wizard Genomic Purification Kit (Promega Corp.).

\section{Molecular genetic analysis}

Samples were genotyped at 13 microsatellite loci [Gam $\mu 1$,

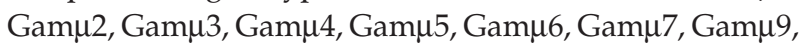

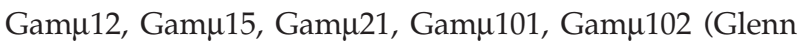
et al. 1997; Jones et al. 2002)] originally designed for the whooping crane (Grus americana) (Glenn 1997). Microsatellite amplification followed procedures previously published for other cranes (Jones et al. 2002; Jones 2003). Fluorescently labelled PCR products were pooled together with an internal size standard (Promega CXR (red) 60-400 bp ladder) and run on an MJ BaseStation automated DNA sequencer (MJ Research). Genotypes were scored using CARTOGRAPHER software (MJ Research).

\section{Subspecies, evolutionary lineage, and breeding location}

To accompany the microsatellite DNA genotypes, data were collected on morphotype (i.e. subspecies) and mtDNA lineage (lineages I and II, Rhymer et al. 2001). For all individuals sampled, birds were categorized by morphology as G.c. canadensis, G. c. rowani, or G. c. tabida using the discriminant methods of Johnson \& Stewart (1973), and mtDNA lineage diagnosed using the PCR-RFLP methods of Glenn et al. (2002). For the MCP, Krapu \& 


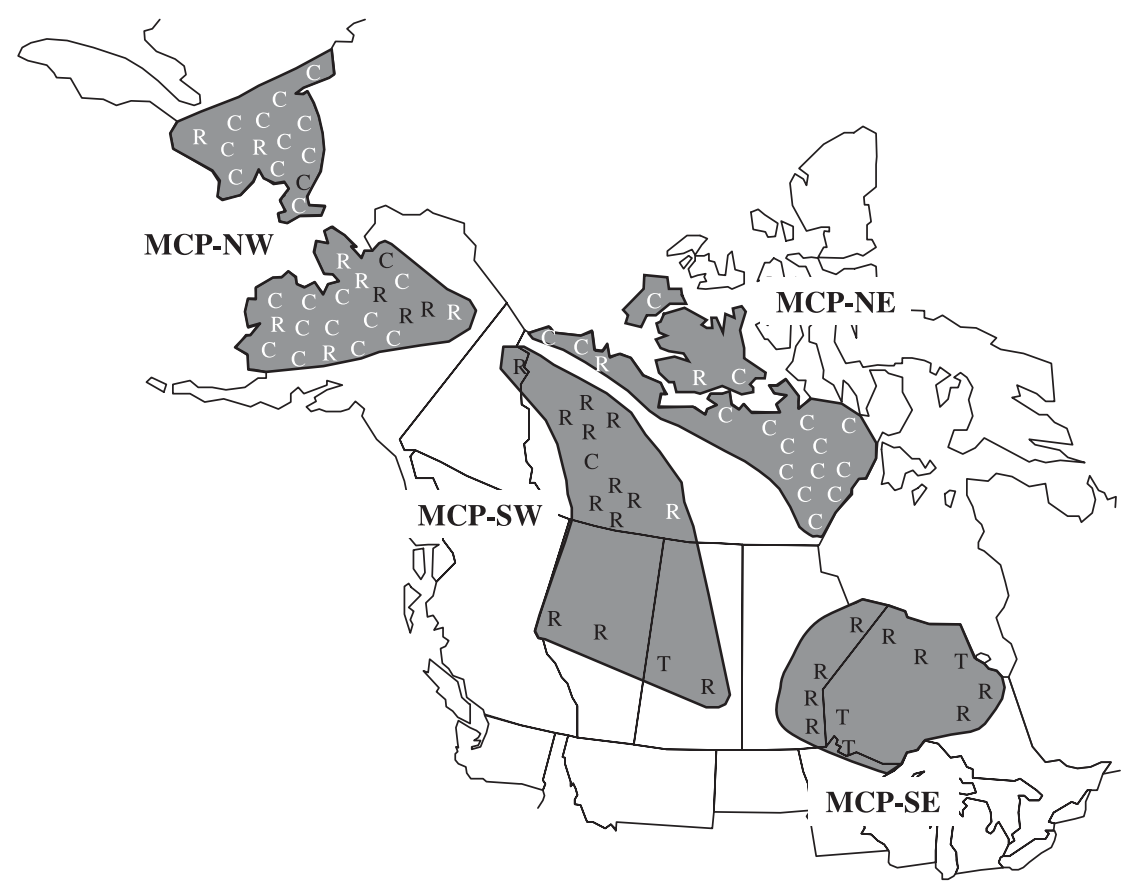

Fig. 2 Distribution of the sandhill crane morphotypes and mtDNA lineages within the Midcontinental population. Approximate geographical placement of the subspecies Grus canadensis canadensis (C), Grus canadensis rowani $(\mathrm{R})$, and Grus canadensis tabida $(\mathrm{T})$, as well as mtDNA lineages I (white) and II (black) based on Krapu \& Brandt's (2002) satellite telemetry are shown. Due to geographical redundancy of some samples, not all birds are represented.
Brandt (2002), captured and marked birds with platform transmitting terminals (PTTs) while at their primary spring staging area in the Central Platte and North Platte river valleys of Nebraska. PTTs were then used to follow bird movements via satellite telemetry. Using GIS coordinates of birds during the breeding season, we defined four geographical regions within the MCP: northwest (MCP-NW), northeast (MCP-NE), southwest (MCP-SW), and southeast (MCP-SE) (Fig. 2). The population was subdivided using the following geographical boundaries: a $300-\mathrm{km}$ span of mountain range within the Yukon Territory, consisting of the Mackenzie and Richardson ranges, separate the MCP-NW birds from the others; the MCP-NE birds were differentiated from those in southern Canada due to their tundra nesting habit; and the MCP-SE region was defined as all birds known to use the southeasternmost migratory route (dashed migratory route, Fig. 1). The subdivisions used here are analogous to the subpopulations delineated by Krapu \& Brandt (2002) except that we have included all birds within Alaska into the MCP-NW group.

The EFP, from the Great Lakes region, is known through banding and radio-tracking to winter in Florida (Walkinshaw 1973; Nesbitt 1975; Lewis 1977), isolated from the MCP. As their breeding and wintering range are not known to overlap with the MCP, the EFP is considered to be a distinct breeding population (Meine \& Archibald 1996). To test this distinction, we used birds sampled from Wisconsin breeding areas as representatives of the EFP in close proximity to the MCP. We know from previous studies that the ranges of MCP and EFP are the closest in the western Great Lakes region (Tacha et al. 1994; Krapu \& Brandt 2002).
Although the breeding range of the RMP is isolated from the $\mathrm{MCP}$, these two populations converge during winter. Birds from the Arctic regions of Canada, Alaska, and Siberia are known to frequent the migratory pathway of the RMP (Krapu \& Brandt 2002, in press). As samples were obtained from the San Luis Valley in Colorado, a known stopover site for this migratory path, morphometric and mitochondrial analyses were used to differentiate the RMP G. c. tabida from MCP G. c. canadensis and G. c. rowani. Birds collected from the San Luis Valley found to be G. c. canadensis or G. c. rowani from the MCP were removed before analysis. We acknowledge this sampling method as a potential source of error. However, from the satellite telemetry to date (Krapu \& Brandt 2002), we have no evidence that the larger birds (i.e. G. c. tabida) of the MCP use the San Luis Valley migration route. Grus canadensis tabida from the MCP overwinter in the Texas Plains and along the Texas Gulf Coast and migrate annually through Nebraska's Central Platte Valley (Krapu \& Brandt 2002).

\section{Microsatellite DNA analyses}

Genetic diversity within breeding locations was explored by calculating the proportion of polymorphic loci, mean number of alleles per locus, mean number of alleles per polymorphic locus, observed heterozygosity $\left(H_{\mathrm{O}}\right)$, and expected heterozygosity $\left(H_{\mathrm{E}}\right)$ using the computer program GENETIC DATA ANALYSIS (GDA, Lewis \& Zaykin 2000). Allelic richness, an estimate of allelic diversity that compensates for unequal sample size, was calculated using FSTAT (Goudet 2001) and averaged across loci. GENEPOP (Raymond 
\& Rousset 1995) was used to determine if populations had significant deviations from Hardy-Weinberg expectations and whether loci exhibit linkage disequilibrium. For both Hardy-Weinberg and disequilibrium analyses, Bonferroni correction (Rice 1989) was used to compensate for multiple comparisons.

Population differentiation was examined using several methods. Using Weir \& Cockerham's (1984) theta $(\theta)$ as an estimator of population co-ancestry coefficient $F_{\mathrm{ST}}$, overall and pairwise analyses of $F_{\mathrm{ST}}$ were conducted using GDA and tested for significance by bootstrapping. Overall and pairwise values for the number of migrants per generation between populations $(\mathrm{Nm})$ were calculated using Slatkin's private allele method (Slatkin 1985; Barton \& Slatkin 1986). An analysis of molecular variance (AMOvA, Excoffier et al. 1992) was carried out and tested for significance by permutation using ARLEQUIN (Schneider et al. 2000). Correlations of allele frequencies and subsequent genotypes between all populations were also investigated with a principal components analysis (PCA) using PCA-GEN, a software program written by Jérôme Goudet, Institute of Ecology, University of Lausanne, Lausanne, Switzerland. From this analysis, a two-dimensional canonical plot was created that represents the first two principal components.

To analyse isolation by distance in the overall study, a Mantel test was carried out on the matrices of genetic distance (in this case the $F_{\mathrm{ST}}$ estimator $\theta$ ) and geographical distance and tested for significance by permutation using GENEPOP. Geographical distance between populations was calculated using the latitude and longitude of the centre point of each group. Additionally, isolation by distance was assessed within the MCP itself. To accomplish this, the two largest subpopulations were divided into two smaller constituent units. Samples within the MCP-NW were divided at the Bering Strait providing Siberian and Alaskan samples; and MCP-SW population was split at the 60th parallel making north and south divisions.

In contrast to the preceding analyses based on userdefined populations, we used the Bayesian-clustering method of Pritchard et al. (2000) to identify cryptic genetic structure using only genotypic data. Pritchard et al.'s (2000) program STRUCTURE, which employs this method, can detect genetic structure without imposing any preconceived ideas of population substructure. This iterative method takes the information from given genotypes and statistically assigns individuals, based on Hardy-Weinberg expectations, to a user-defined number of anonymous genetic clusters $(K)$, thus elucidating genetic structure that may not be apparent otherwise. To analyse genetic structure within and between the sandhill populations, STRUCTURE was used to perform six independent analyses using simulations of 50000 burn-in iterations and 100000 data iterations to assign individuals into $K=1-6$ populations, respectively. The posterior probability of $K(P(K \mid X))$ was determined using the methods of Pritchard et al. (2000). After the STRUCTURE analysis was carried out, individual admixture proportions (i.e. the proportion of an individual's genetics assigned to each genetic cluster) were sorted and displayed by population.

\section{Results}

Among the samples used in this study, we identified the three size morphs from Johnson \& Stewart (1973) that correspond with the subspecies definitions of Grus canadensis canadensis, Grus canadensis rowani, and Grus canadensis tabida. Although the small morph (G.c.canadensis) was found only in the northern reaches of the MCP and the larger morph (G.c. tabida) found only in the lower portions, the intermediate morph (G. c. rowani) has considerable overlap with both northern and southern forms (Table 2). The approximate placement of each sample based on satellite telemetry (Fig. 2), provides insight to subspecies placement within the MCP and the extent of subspecies mixing. The mixing of the subspecies within the central regions of the MCP was better illustrated when the information from mtDNA sequence analysis was overlaid (Fig. 2). As expected for the EFP, and defined for the RMP, the southern populations contained only large-bodied (G.c. tabida) birds with type II mtDNA (Table 2).

Table 2 Subspecific composition of sampled populations

\begin{tabular}{|c|c|c|c|c|c|c|c|}
\hline \multirow[b]{2}{*}{ Population } & \multirow{2}{*}{$\begin{array}{l}\text { Number } \\
\text { sampled }\end{array}$} & \multirow{2}{*}{$\begin{array}{l}\text { Breeding location } \\
\text { assumptions }\end{array}$} & \multicolumn{3}{|c|}{$\begin{array}{l}\text { Proportions of each } \\
\text { morphotypic subspecies }\end{array}$} & \multicolumn{2}{|c|}{$\begin{array}{l}\text { Proportions } \\
\text { of each mtDNA } \\
\text { lineage }\end{array}$} \\
\hline & & & G.c.canadensis & G.c. rowani & G.c. tabida & I & II \\
\hline MCP-NW & 40 & Known (PTT) & 0.75 & 0.25 & 0.00 & 0.87 & 0.13 \\
\hline MCP-NE & 21 & Known (PTT) & 0.91 & 0.09 & 0.00 & 1.00 & 0.00 \\
\hline MCP-SW & 16 & Known (PTT) & 0.06 & 0.88 & 0.06 & 0.06 & 0.94 \\
\hline MCP-SE & 14 & Known (PTT) & 0.00 & 0.79 & 0.21 & 0.00 & 1.00 \\
\hline $\mathrm{RMP}$ & 26 & Inferred & 0.00 & 0.00 & 1.00 & 0.00 & 1.00 \\
\hline EFP & 74 & Known (radio telemetry) & 0.00 & 0.00 & 1.00 & 0.00 & 1.00 \\
\hline
\end{tabular}


Table 3 Descriptive statistics for each population derived from multilocus microsatellite DNA genotypes

\begin{tabular}{lllllllll}
\hline & $\begin{array}{l}\text { Number of } \\
\text { samples } \\
\text { genotyped }\end{array}$ & $\begin{array}{l}\text { Proportion of } \\
\text { polymorphic } \\
\text { loci }\end{array}$ & $\begin{array}{l}\text { Alleles per } \\
\text { locus }\end{array}$ & $\begin{array}{l}\text { Alleles per } \\
\text { polymorphic } \\
\text { locus }\end{array}$ & $\begin{array}{l}\text { Allelic } \\
\text { richness }\end{array}$ & $\begin{array}{l}\text { Expected } \\
\text { heterozygosity } \\
\left(H_{\mathrm{E}}\right)\end{array}$ & $\begin{array}{l}\text { Observed } \\
\text { heterozygosity } \\
\left(H_{\mathrm{O}}\right)\end{array}$ & $\begin{array}{l}\text { Inbreeding within } \\
\text { subpopulations } \\
\left(F_{\mathrm{IS}}\right)\end{array}$ \\
\hline MCP-NW & 40 & 0.92 & 5.08 & 5.42 & 4.31 & 0.52 & 0.42 & $0.20^{*}$ \\
MCP-NE & 21 & 0.92 & 5.31 & 5.67 & 4.81 & 0.55 & 0.48 & $0.14^{*}$ \\
MCP-SW & 16 & 0.92 & 4.38 & 4.67 & 4.25 & 0.54 & 0.43 & $0.22^{*}$ \\
MCP-SE & 14 & 0.92 & 3.92 & 4.17 & 3.92 & 0.54 & 0.48 & 0.10 \\
RMP & 26 & 0.85 & 3.92 & 4.46 & 3.54 & 0.49 & 0.44 & 0.11 \\
EFP & 74 & 0.92 & 3.92 & 4.17 & 3.35 & 0.49 & 0.43 & $0.13^{*}$ \\
\hline
\end{tabular}

*Significant heterozygote deficiency $(P<0.05)$.

Table 4 Locus-by-locus tests for Hardy-Weinberg equilibrium. For each locus, $F_{\text {IS }}$ values indicate lack (positive) or excess (negative) of heterozygosity. Dashes indicate monomorphic loci

\begin{tabular}{lccccccc}
\hline Locus & MCP-NW & MCP-NE & MCP-SW & MCP-SE & RMP & EFP \\
\hline Gam $\mu 1$ & 0.08 & 0.15 & 0.10 & 0.09 & 0.21 & $0.30^{*}$ \\
Gam 42 & - & - & - & - & - & - \\
Gam $\mu 3$ & 0.21 & 0.08 & 0.07 & -0.18 & 0.07 & 0.13 \\
Gam $\mu 4$ & 0.46 & 0.47 & 0.46 & -0.04 & 0.66 & 0.31 \\
Gam $\mu 5$ & 0.17 & 0.16 & 0.24 & 0.32 & 0.16 & $0.31^{*}$ \\
Gam $\mu 6$ & 0.13 & 0.03 & 0.12 & 0.14 & 0.04 & 0.06 \\
Gam $\mu 7$ & $0.56^{*}$ & $0.76^{*}$ & $0.66^{*}$ & 0.27 & 0.24 & 0.14 \\
Gam $\mu 9$ & 0.36 & 0.02 & 0.28 & 0.32 & 0.13 & 0.10 \\
Gam $\mu 12$ & 0.19 & -0.25 & -0.05 & -0.08 & - & -0.02 \\
Gam $\mu 15$ & 0.14 & -0.08 & 0.06 & 0.32 & 0.30 & 0.02 \\
Gam $\mu 21$ & $0.55^{*}$ & 0.34 & 0.34 & 0.11 & 0.01 & 0.07 \\
Gam $\mu 101$ & -0.01 & -0.19 & 0.10 & -0.13 & -0.10 & 0.14 \\
Gam $\mu 102$ & -0.11 & 0.01 & 0.08 & -0.07 & 0.13 & -0.09 \\
\hline
\end{tabular}

*Significant heterozygote deficiency after Bonferroni correction $(P<0.05)$.

The microsatellite DNA genotypes (Jones 2003; available online from http://www.savingcranes.org) exhibited no evidence of linkage disequilibrium; however there were deviations from Hardy-Weinberg expectations. All populations showed heterozygote deficiencies, with MCP-NW, MCP-NE, MCP-SE, and EFP significantly so $(P<0.05)$ after Bonferroni correction (Table 3 ). To explore this deficiency further, a locus-by-locus presentation of $F_{\text {IS }}$ (Table 4) illustrates that the reduction in observed heterozygosity involved multiple loci that exhibit equilibrium in other populations and other species (Jones et al. 2002; Jones 2003), thus the deficiency is likely due to population history or structure, not genotyping problems (e.g. null alleles). Although we did not see evidence of null genotypes (e.g. no individuals failed to produce PCR products), PCR competition can cause one of the two alleles at a locus to amplify at a lower rate thus providing an erroneous homozygote genotype (allelic dropout). To detect and reduce the
Table 5 Alleles found in only one population (i.e. private alleles)

\begin{tabular}{|c|c|c|c|}
\hline Locus & Allele & Frequency & Found in \\
\hline Gamp12 & 119 & 0.01 & MCP-NW \\
\hline Gamp5 & 196 & 0.01 & MCP-NW \\
\hline Gamp102 & 139 & 0.04 & MCP-NW \\
\hline Gam $\mu 1$ & 150 & 0.02 & MCP-NE \\
\hline Gam $\mu 1$ & 146 & 0.02 & MCP-NE \\
\hline Gamp102 & 145 & 0.02 & MCP-NE \\
\hline Gam $\mu 7$ & 143 & 0.02 & MCP-NE \\
\hline Gamp3 & 131 & 0.02 & MCP-NE \\
\hline Gamp6 & 143 & 0.10 & MCP-NE \\
\hline Gamp7 & 149 & 0.10 & MCP-NE \\
\hline Gamp12 & 125 & 0.03 & MCP-SW \\
\hline Gamp5 & 176 & 0.03 & MCP-SW \\
\hline Gam $\mu 21$ & 128 & 0.04 & MCP-SE \\
\hline Gam $\mu 102$ & 148 & 0.04 & MCP-SE \\
\hline Gamp6 & 136 & 0.02 & $\mathrm{RMP}$ \\
\hline Gam $\mu 9$ & 183 & 0.02 & RMP \\
\hline Gamp6 & 138 & 0.06 & RMP \\
\hline Gam $\mu 1$ & 134 & 0.01 & EFP \\
\hline Gamp21 & 140 & 0.01 & EFP \\
\hline Gam $\mu 21$ & 142 & 0.01 & EFP \\
\hline Gamp101 & 237 & 0.03 & EFP \\
\hline Gamp102 & 124 & 0.05 & EFP \\
\hline
\end{tabular}

possibility of allelic dropout, we genotyped homozygote individuals multiple times. With respect to gene diversity $\left(H_{\mathrm{E}}\right)$, allelic diversity, allelic richness, as well as private alleles, only nonsignificant differences were seen between populations (Tables 3 and 5).

Significant $F_{\mathrm{ST}}$ values $(P<0.05)$ were found overall and for most pairwise combinations of populations (Table 6), with all regions of the MCP significantly differentiated from the RMP and EFP samples. The MCP appears to follow an isolation-by-distance model of population divergence, where adjacent regions (MCP-NW, MCP-SW, and MCP-NE; and MCP-SW and MCP-SE, respectively) are not significantly different with respect to their allele frequencies and regions farthest apart (MCP-NW and MCP-SE; and 
(a) Isolation by distance using all populations

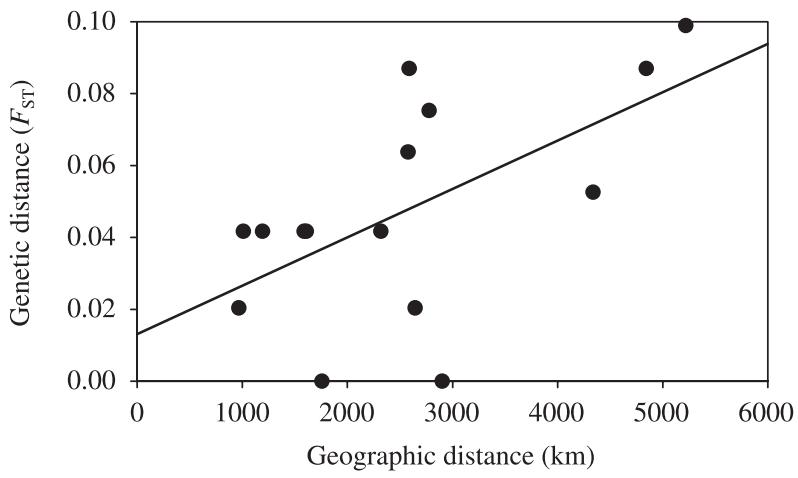

(b) Isolation by distance within the Midcontinent population only

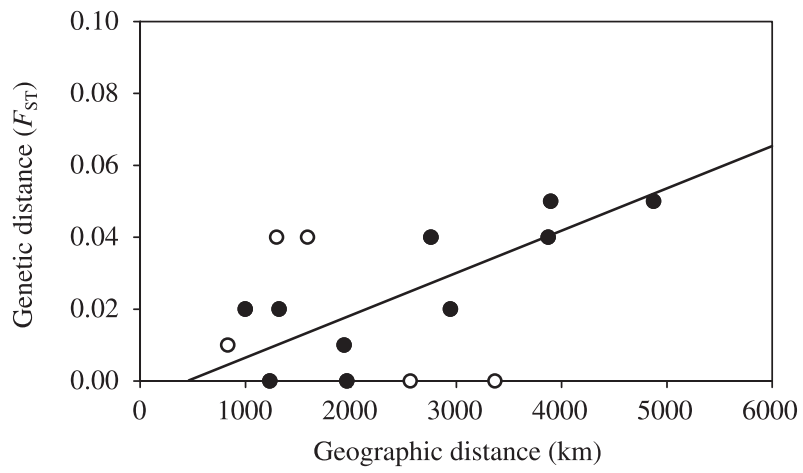

Fig. 3 Pairwise estimates of $F_{\mathrm{ST}}$ plotted against geographical distance over all populations (a) and for the Midcontinental population only (b). Regression lines are shown. Open circles (b) represent comparisons with the MCP-NE subpopulation.

Table 6 Overall and pairwise estimates of $F_{\mathrm{ST}}$ (lower) and $N m$ (upper) based on microsatellite DNA genotypes. Asterisks indicate significant deviations $(P<0.05)$ of allele frequencies across all loci

\begin{tabular}{lllllll}
\hline \multicolumn{9}{c}{ MCP-NW } & MCP-NE & MCP-SW & MCP-SE & RMP & EFP \\
\hline MCP-NW & - & 3.65 & 2.26 & 1.41 & 1.42 & 1.01 \\
MCP-NE & $0.00 \mathrm{NS}$ & - & 3.75 & 2.05 & 1.84 & 2.02 \\
MCP-SW & $0.02 \mathrm{NS}$ & $0.02 \mathrm{NS}$ & - & 2.68 & 2.62 & 1.21 \\
MCP-SE & $0.05^{*}$ & $0.04^{*}$ & $0.00 \mathrm{NS}$ & - & 2.42 & 1.36 \\
RMP & $0.08^{*}$ & $0.07^{*}$ & $0.04^{*}$ & $0.04^{*}$ & - & 1.89 \\
EFP & $0.09^{*}$ & $0.08^{*}$ & $0.06^{*}$ & $0.04^{*}$ & $0.04^{*}$ & - \\
Overall $F_{\mathrm{ST}}$ & $0.06^{*}$ & & & & & \\
Overall Nm & 3.66 & & & & & \\
\hline
\end{tabular}

MCP-NE and MCP-SE, respectively) have significantly different allele frequencies $(P<0.05)$ (Table 6). Analysis for geographical similarity of allele frequencies (Fig. 3) indicates that $F_{\mathrm{ST}}$ is positively correlated to geographical distance between all populations (Fig. 3a; $r=0.59, P=0.03$ ), yet shows that within the MCP isolation by distance is more constrained. Within the conglomerate of MCP as a whole, geographical distance is weakly correlated to genetic distance $(r=0.45$,

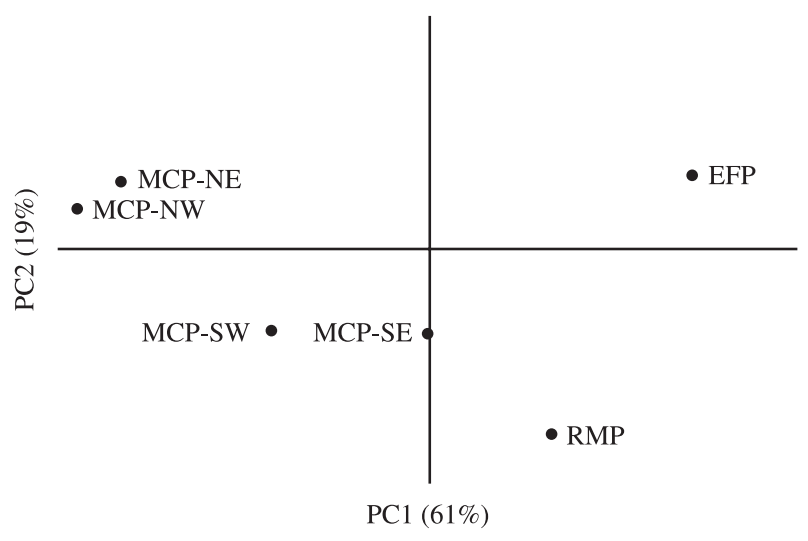

Fig. 4 Canonical plot of the first two principal components illustrate the partitioning of variance of overall $F_{\mathrm{ST}}$ across all populations. Graphical proximity conveys information on correlations of allele frequencies between populations presumably due to coancestry and/or gene flow.

$P=0.09$ ). However, if comparisons involving MCP-NE (open circles) are removed from the analysis, the association of genetic to geographical distance becomes much stronger $(r=0.82, P=0.01)$.

Like the estimates of $F_{\mathrm{ST}}$, gene flow estimates $(\mathrm{Nm})$, based on the number and frequency of private alleles indicates a high rate of gene flow within the MCP (Table 6). Although $N m$ estimates are lower between the MCP, EFP, and RMP, $\mathrm{Nm}$ rates greater than one migrant per generation indicate that a low level of gene flow may exist between all migratory populations (Mills \& Allendorf 1996 and citations therein). Similarly, the analysis of molecular variance shows that most of the genetic variability lies within populations $(93.3 \%, P<0.001)$, and only a small amount of the variation $(4.2 \%, P=0.068)$ is due to the differences among the three migratory populations and among the subpopulations of the MCP $(2.5 \%, P<0.001)$. Additional hierarchical analyses for samples within the MCP reveal that little variation is explained by morphological subspecies $(1.3 \%, P=0.025)$ and mtDNA haplotype differences approximate that of the geographically derived subpopulations $(2.5 \%, P<0.001)$. In a visual representation of $F_{\mathrm{ST}}$, the PCA (Fig. 4) illustrates the pattern of gene flow within the $\mathrm{MCP}$, as well as between the MCP, EFP and RMP.

Although individuals within six geographical groups were tested, the Bayesian STRUCTURE analysis revealed the highest posterior probability for four genetic clusters $(P(K \mid X)=0.95$, Table 7). To explore the geographical placement of these genetic clusters, we sorted and graphed the individual admixture proportions by population (Fig. 5). Where two genetic clusters were specified $(K=2)$, the genetic variation clustered such that it illustrated a basic difference between far northern birds (e.g. Arctic nesting) and all other birds. A new grouping, consistent with admixture between the two initial genetic clusters, was delineated 
(a) $K=2$ (Individual admixture proportions)



(b) $K=2$ (Population admixture proportions)

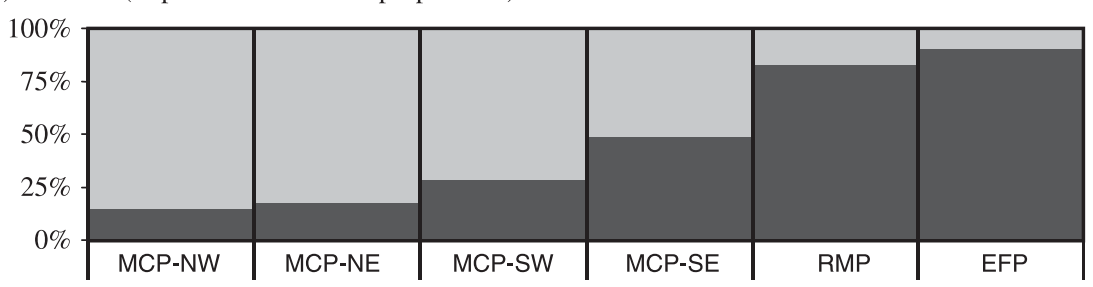

(c) $K=3$ (Individual admixture proportions)

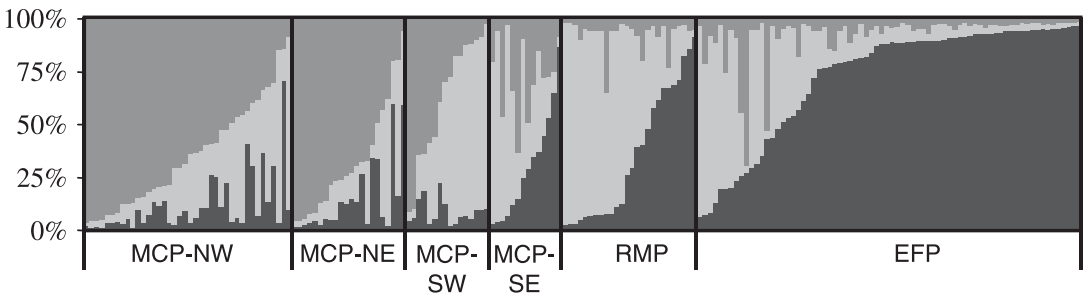

(d) $K=3$ (Population admixture proportions)

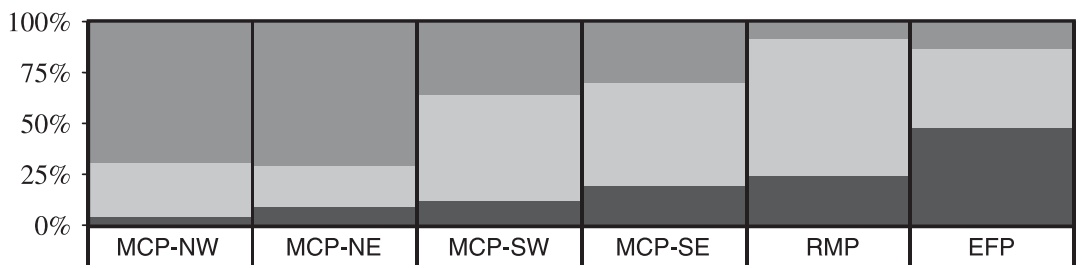

Fig. 5 Bayesian analysis of the microsatellite DNA genetic structure. The proportion of ancestry assigned to each of the $K$ subgroups was plotted for each population by individuals $(a, c)$, and by population mean $(b, d)$.
Table 7 Inferred number of genetic clusters $(K)$

\begin{tabular}{llc}
\hline$K$ & $\log P(X \mid K)$ & $P(K \mid X)$ \\
\hline 1 & -5637.3 & $\sim 0$ \\
2 & -5414.2 & $\sim 0$ \\
3 & -5384.1 & $\sim 0$ \\
4 & -5361.1 & 0.95 \\
5 & -5364.2 & 0.05 \\
6 & -5404.5 & $\sim 0$ \\
\hline
\end{tabular}

when the variance was partitioned further $(K=3)$. The primary geographical placement of this admixture again suggests isolation by distance for the microsatellite DNA variation. When $K=4$ was used (the value with the highest posterior probability), the analysis only served to subdivide the admixed variation further. As the admixture proportions for $K=4-6$ did not elucidate any new genetic structure, they are not presented here.

\section{Discussion}

The sandhill cranes are the most numerous, and one of the most genetically diverse, species of crane. Our data show that although the estimates of allelic richness and gene diversity $\left(H_{\mathrm{E}}\right)$ are low compared to many bird species (Neff \& Gross 2001), of the five crane species sampled to date, the sandhill cranes are second only to red-crowned cranes (Grus japonensis) in overall diversity (Hasegawa et al. 2000; Jones et al. 2002; Jones 2003). One notable detail in the data is significant heterozygote deficiencies in the majority of groups tested. While genotyping errors or null alleles cannot be completely eliminated as an explanation, we feel that demographic history is a more likely explanation. As the boundaries of the MCP regions were inferred through geographical or migratory differences, they may not represent true genetic boundaries. Given that this species has a high degree of natal philopatry (Walkinshaw 1949; Littlefield 1968; Drewien 1974; Littlefield \& Ivey 1995; Nesbitt et al. 
2002), the geographical boundaries used in this study likely encompass many localized demes. Population genetic theory suggests that if a population contains multiple demes, an excess of homozygosity is likely to be found (i.e. the Wahlund effect, Wahlund 1928). Although the EFP also shows a significant lack of heterozygotes (Table 4), the root cause may be different. It is known that the midwest sector of the EFP went through a severe population reduction within the last 100 years and was almost completely extirpated from Wisconsin by 1930 (Henika 1936; Leopold 1949; Walkinshaw 1949, 1973). The sandhill crane sample from Wisconsin shows both reduced allelic richness and heterozygote deficiency that likely reflects this population bottleneck.

With regard to allelic differentiation among populations, there were few microsatellite alleles unique to any one population. No private alleles were observed at a frequency higher than 10\% (Table 5). The population-level analyses uncovered only slight differences between any two populations (i.e. $F_{\mathrm{ST}}<0.05$ is considered little differentiation, Wright 1978; Hartl \& Clark 1997). The results of this study show that the nuclear diversity, within the MCP and overall, is clinal throughout the 6000-kilometre-wide range. As evidenced by a nonsignificant $F_{\mathrm{ST}}$, no discernable differences in microsatellite DNA allele frequencies were seen between the two regions where lineage I mtDNA predominated (MCP-NW and MCP-NE, Table 6). Gene flow between these two regions is sufficient to sustain similarity of allele frequencies (Table 6). Although the subspecific composition of these two northern regions is different from the southern regions (Table 2), neither MCP-NW or MCP-NE has a significant difference in allele frequencies compared to samples from the MCP-SW region (Table 6). These results in tandem with nonsignificant $F_{\mathrm{ST}}$ estimates between MCP-SW and MCP-SE regions and significant $F_{\mathrm{ST}}$ estimates between the MCP-SE and MCP-NW/MCP-NE (Table 6) indicate isolation by distance. This north/south cline is echoed throughout the results of this study [e.g. morphologic and mtDNA subspecific composition (Table 2), Nm (Table 6), PCA (Fig. 4), and the STRUCTURE analysis (Fig. 5)]. To further test for isolation by distance of these populations, a Mantel test of geographical and genetic distance between migratory populations showed a significant $(P<0.03)$ positive association between genetic differentiation and interpopulation distance (Fig. 3a). Although the majority of the comparisons within the MCP (Fig. 3b) showed a similar tendency for isolation by distance (filled circles), comparisons involving MCP-NE (open circles) indicate that gene flow to and from this subpopulation do not follow a simple isolation-by-distance model. Comparisons of MCP-NE and the constituent samples of the MCP-NW (Siberia and Alaska) (lower right open circles) show that the distance between the Arctic regions is not a significant barrier to gene flow. Conversely, comparisons among MCP-NE, southern MCP-SW, and MCP-SE (upper left open circles) suggest that the Canadian Shield, a sterile rocky landscape produced by glaciation that separates MCP-NE from the central and southern sectors of the population, is producing a barrier to gene flow.

The analyses in total show only slight allele frequency differences between the MCP and the other migratory populations. It has long been known that the MCP cranes intermingled with those of the RMP in their wintering grounds (Lewis 1977), thus it is not surprising that these two populations are genetically similar. In relation to the genetic connectivity of the EFP and the MCP, it is plausible that the MCP and the EFP have occasional genetic interchange. Tacha et al. (1994) suggested that transition from MCP to the EFP was near the Ontario/Manitoba border in south central Canada. However, via satellite telemetry, we now know that the birds in western Ontario are in fact a part of the MCP (Krapu \& Brandt 2002). Thus, the transition from MCP to EFP runs from central Minnesota across to southeastern Ontario (Fig. 1). Although it is known that the MCP and EFP over-winter in different locations, their breeding populations are nearly contiguous. Due to fluctuations in range, it is likely that gene flow could occasionally occur between these populations.

\section{Subspecies discrimination}

The microsatellite and mtDNA data in combination with information on morphology and geography provide new insights into the history of the MCP. Given that the G. c. canadensis morph and mtDNA lineage I remain clustered mainly in the north and that the larger body morphs of G. c. rowani and G. c. tabida and mtDNA lineage II remain mainly south (Fig. 2, Table 2), it is easy to see how previous studies have come to the conclusion that the population is heavily subdivided with only occasional hybridizations (Walkinshaw 1949, 1965; Johnson \& Stewart 1973; Lewis 1977; Aldrich 1979; Meine \& Archibald 1996; Rhymer et al. 2001; Glenn et al. 2002; Petersen et al. 2003). However, taken in context with the precise geographical information, the morphologic and microsatellite DNA variation shows that there is a gradation from the Arctic-nesting G. c. canadensis to the non-Arctic G. c. tabida (Figs 2, 4 and 5; Tables 2 and 6). Although the results of this study, like previous studies, nullify G. c. rowani as a genetically distinct subspecies, these results also nullify the possibility of these birds being simply an alternate body form of the G. c. tabida. Data to date indicate that this morphotype is intermediate in morphology, geography, and genetics. Given the new data on nuclear similarity to both northern and southern birds, the G. c. rowani subspecies should be considered a transitional form, as suggested previously (Stephen 1967; Tacha et al. 1985; Rhymer et al. 2001; Petersen et al. 2003). 


\section{Pleistocene glaciation and sandhill cranes}

By providing a nuclear data set matched with mtDNA, morphology and geographical data, this study provides a great opportunity to advance the knowledge of this species. We can now examine the data and look for clues to historical and ongoing processes that have shaped the populations we see today. Given the considerable sequence divergence in mtDNA lineages shown by Rhymer et al. (2001), it is not likely that this divergence could have evolved in the face of current levels of gene flow. Similarly to other North American species (Klicka \& Zink 1997, 1999; Avise \& Walker 1998), Rhymer et al. (2001) suggests the degree of mtDNA divergence seen in sandhills presumably dates to the mid-Pleistocene. Similar to other arctic populations [e.g. marbled murrelets, Brachyramphus marmoratus (Congdon et al. 2000), common guillemot, Uria aalge (Friesen et al. 1996), and Canada geese (Van Wagner \& Baker 1990)], it is likely that what we see in the MCP today reflects secondary contact of a previously subdivided population.

The results of this study, showing the sandhill mtDNA localized in a north/south pattern and the morphometric and nuclear variation clinal, suggest that the current MCP is, in part, the result of postglaciation secondary contact. The Beringian glacial refugium, an area of eastern Siberia and western Alaska that remained unglaciated throughout the Pleistocene, was an ecological refuge where many species survived the Pleistocene glaciation (Hopkins et al. 1982). This unglaciated area coincides with westernmost limit of this species and represents the area currently occupied by the birds of the MCP-NW region, a stronghold of the birds with lineage I mtDNA. It is likely that the ancestral population of sandhill cranes, that resided in North America for millions of years prior to the Pleistocene (Brodkorb 1967), were bisected by the progression of early Pleistocene glaciation, producing two refugia, one in Beringia or west of the glaciers extent on the Siberian steppe and one in the southern portions of North America. These refugia remained isolated a sufficient amount of time to evolve significant differences in mtDNA sequence (Rhymer et al. 2001). At the end of the last glaciation event (c. 11000 вр), the Laurentide and Cordilleran ice sheets retreated and produced an ice-free migratory corridor from Beringia to the southern portions of North America (Arnold 2002). Upon expansion of the Siberian/Beringian population of G. c. canadensis southeast and the southern population of G. c. tabida northwest, this corridor which parallels the east slope of the Canadian Rockies, was a region of secondary contact and introgression.

With the high degree of nuclear gene flow seen in this study, coalescence theory would have predicted a population structure more similar to that of snow geese (Avise et al. 1992). As mtDNA has a much faster coalescence time (one-fourth that of nuclear genes), the mtDNA lineages would have spread throughout the population well before that of the nuclear microsatellite DNA if random mating existed. However, given that mtDNA variation in this population is still highly structured geographically and that the nuclear DNA variation is clinally distributed, strong female natal philopatry and male mediated gene flow is suggested. It is not known whether the MCP is currently in genetic equilibrium or whether the integration of these two refugia populations is still in progress. Continued monitoring of the genetic composition of the MCP may provide insight into rates of introgression. If the intermediate morphology of the G. c. rowani does in fact result from the hybridization between G. c. canadensis and G. c. tabida, this morph will become more common in areas of the range where it is advantageous, or remain localized if it is disadvantageous (Rhymer \& Simberloff 1996). Conversely, if the population is currently in equilibrium, the G. c. rowani morph may represent a physiological intermediate adapted to more median environments. In any case, the MCP should be considered a single genetic population whose origin stems from the introgression of two formerly divided populations. As with the snow goose (Avise et al. 1992), given the high rates of gene flow that exist today, any genetic differentiation remaining in the MCP today will likely decline over time.

\section{Acknowledgements}

We thank Jeb Barzen, Matt Hayes, and Jim Gammonley for providing additional blood samples needed for this study and Doug Johnson for assistance in classifying MCP cranes to subspecies. We also thank the USGS Northern Prairie Wildlife Research Center (Grant no. 01CRAG0003), the International Crane Foundation, and the Colorado Division of Wildlife for their generous financial and logistic support for the project; also Doug Johnson and three anonymous reviewers for their helpful comments on the manuscript. In addition to the direct funding for this project, this study benefited from previous support through grants from the US Fish and Wildlife Service and US Geological Survey under the Webless Migratory Game Bird Research Program, Central Flyway State Wildlife Management Agencies, The Playa Lakes Joint Venture, International Crane Foundation, and the US Geological Survey under the Platte River Program to G.L. Krapu for his satellite telemetry research on Midcontinental sandhill cranes. This research was completed in partial fulfillment of the requirements for the doctoral degree of K.L. Jones at the Graduate College of the University of Illinois at Chicago.

\section{References}

Aldrich JW (1972) A new subspecies of sandhill cranes from Mississippi. Proceedings of the Biological Society of Washington, 85, 63-70.

Aldrich JW (1979) Status of the Canadian sandhill crane. In: Proceedings of the 1978 Crane Workshop (ed. Lewis JC), pp. 139-148. Colorado State University and National Audubon Society, Fort Collins, Colorado.

Arnold TG (2002) Radiocarbon dates from the ice-free corridor. Radiocarbon, 44, 437-454. 
Avise JC, Walker D (1998) Pleistocene phylogeographic effects on avian populations and the speciation process. Proceedings of the Royal Society of London. Series B, Biological Sciences, 265, 457-463.

Avise JC, Alisauskas RT, Nelson WS, Ankney CD (1992) Matriarchal population genetic-structure in an avian species with female natal philopatry. Evolution, 46, 1084-1096.

Avise JC, Walker D, Johns GC (1998) Speciation durations and Pleistocene effects on vertebrate phylogeography. Proceedings of the Royal Society of London. Series B, Biological Sciences, 265, 1707-1712.

Ball RM, Avise JC (1992) Mitochondrial DNA phylogeographic differentiation among avian populations and the evolutionary significance of subspecies. Auk, 109, 626-636.

Bangs O, Zappey WR (1905) Birds from the Isle of Pines. American Naturalist, 39, 179-215.

Barton NH, Hewitt GM (1985) Analysis of hybrid zones. Annual Review of Ecology and Systematics, 16, 113-148.

Barton NH, Slatkin M (1986) A quasi-equilibrium theory of the distribution of rare alleles in a subdivided population. Heredity, 56, 409-415.

Brodkorb P (1967) Catalogue of fossil birds. Part 3. (Ralliformes, Ichthyornithiformes, Charadriiformes). Bulletin of the Florida State Museum, Biological Science, 2, 199-220.

Congdon BC, Piatt JF, Martin K, Friesen VL (2000) Mechanisms of population differentiation in marbled murrelets: historical versus contemporary processes. Evolution, 54, 974-986.

Drewien RC (1974) Ecology of Rocky Mountain greater sandhill cranes. PhD Dissertation. University of Idaho, Moscow, Idaho.

Drewien RC, Brown WM, Benning DS (1996) Distribution and abundance of sandhill cranes in Mexico. Journal of Wildlife Management, 60, 270-285.

Drewien RC, Brown WM, Varley JD, Lockman DC (1999) Seasonal movements of sandhill cranes radiomarked in Yellowstone National Park and Jackson Hole, Wyoming. Journal of Wildlife Management, 63, 126-136.

Excoffier L, Smouse PE, Quattro JM (1992) Analysis of molecular variance inferred from metric distances among DNA haplotypes - application to human mitochondrial-DNA restriction data. Genetics, 131, 479-491.

Friesen VL, Montevecchi WA, Baker AJ, Barrett RT, Davidson WS (1996) Population differentiation and evolution in the common guillemot Uria aalge. Molecular Ecology, 5, 793-805.

Gaines GD, Warren RJ (1984) Genetics and morphology of sandhill crane populations in Texas. Journal of Wildlife Management, 48, 1387-1393.

Gammonley JH, Laubhan MK (2002) Spring stopover food resources and land use patterns of Rocky Mountain population sandhill cranes in the San Luis Valley, Colorado. In: Webless Migratory Game Bird Research Program (ed. Dolton DD), pp. 24 27. US Fish and Wildlife Service, Division of Migratory Bird Management, Denver, Colorado.

Glenn TC (1997) Genetic bottlenecks in long-lived vertebrates: mitochondrial and microsatellite DNA variation in American alligators and whooping cranes. PhD Dissertation. University of Maryland, College Park, Maryland.

Glenn TC, Ojerio W, Stephan W, Braun MJ (1997) Microsatellite DNA loci for genetic studies of cranes. In: Proceedings of the 7 th North American Crane Workshop (eds Urbanek RP, Stahlecker DW), pp. 36-45. North American Crane Working Group, Grand Island, Nebraska.

Glenn TC, Thompson JE, Ballard BM, Roberson JA, French JO (2002) Mitochondrial DNA variation among wintering midcontinent gulf coast sandhill cranes. Journal of Wildlife Management, $66,339-348$.
Goudet J (2001) FSTAT (Version 2.9.3), a program to estimate and test gene diversities and fixation indices. Available from http:// www.unil.ch/izea/softwares/fstat.html.

Hartl DL, Clark AG (1997) Principles of Population Genetics, 3rd edn. Sinauer Associates, Sunderland, Massachusetts.

Hasegawa O, Ishibashi Y, Abe S (2000) Isolation and characterization of microsatellite loci in the red-crowned crane Grus japonensis. Molecular Ecology, 9, 1677-1678.

Hayes MA, Hartup BK, Pittman JM, Barzen JA (2003) Capture of sandhill cranes using alpha-chloralose. Journal of Wildlife Diseases, 39, 859-868.

Henika FS (1936) Sandhill cranes in Wisconsin and other lake states. Proceedings of the North American Wildlife Conference, 1, 644-646.

Hewitt GM (1996) Some genetic consequences of ice ages, and their role in divergence and speciation. Biological Journal of the Linnean Society, 58, 247-276.

Holder K, Montgomerie R, Friesen VL (1999) A test of the glacial refugium hypothesis using patterns of mitochondrial and nuclear DNA sequence variation in rock ptarmigan (Lagopus mutus). Evolution, 53, 1936-1950.

Hopkins DM, Matthews JV, Schweger CE, Young SB, eds. (1982) Paleobiology of Beringia. Academic Press, New York.

Ivey GL, Herziger CP, Hoffmann TJ (2005) Tracking movements of sandhill cranes through their annual cycle from Ridgefield NWR, Washington, and Sauvie Island WA, Oregon. Proceedings of the Ninth North American Crane Workshop, 9 (in press).

Johnsgard PA (1983) Cranes of the World. Indiana University Press, Bloomington, Indiana.

Johnson DH, Stewart RE (1973) Racial composition of migrant populations of sandhill cranes in the northern plains states. Wilson Bulletin, 85, 148-162.

Jones KL (2003) Genetic variation and structure in cranes: a comparison among species. PhD Dissertation. University of Illinois - Chicago, Chicago, Illinois.

Jones KL, Glenn TC, Lacy RC et al. (2002) Refining the whooping crane studbook by incorporating microsatellite DNA and leg-banding analyses. Conservation Biology, 16, 789-799.

Klicka J, Zink RM (1997) The importance of recent ice ages in speciation - a failed paradigm. Science, 277, 1666-1669.

Klicka J, Zink RM (1999) Pleistocene effects on North American songbird evolution. Proceedings of the Royal Society of London. Series B, Biological Sciences, 266, 695-700.

Krapu GL, Brandt DA (2002) Delineation of subpopulations of midcontinent sandhill cranes and their relative abundance based on satellite telemetry. In: Webless Migratory Game Bird Research Program (ed. Dolton DD), pp. 28-30. US Fish and Wildlife Service, Division of Migratory Bird Management, Denver, Colorado.

Krapu GL, Brandt DA (2005) Migration routes, staging areas, and wintering grounds of sandhill cranes that breed in Siberia. Proceedings of the Ninth North American Crane Workshop, 9 (in press).

Leopold A (1949) A Sand County Almanac and Sketches Here and There. Oxford University Press, New York.

Lewis JC (1977) Sandhill crane. In: Management of Migratory Shore and Upland Game Birds in North America (ed. Sanderson GC), pp. 4-43. International Association of Fish and Wildlife Agencies, Washington, D.C.

Lewis PO, Zaykin D (2000) Genetic data analysis: computer program for the analysis of allelic data, Version 1.0 (d12). Available from http://alleyn.eeb.uconn.edu/gda/

Littlefield CD (1968) Breeding biology of the greater sandhill crane on 
Malheur National Wildlife Refuge, Oregon. PhD Dissertation. Colorado State University, Fort Collins, Colorado.

Littlefield CD, Ivey GL (1995) An unusual record of sandhill crane philopatry. Wilson Bulletin, 107, 766.

Longmire JL, Ambrose RE, Brown NC, Cade TJ, Maechtle T, Seegar WS, Ward FP, White CM (1991) Use of sex-linked minisatellite fragments to investigate genetic differentiation and migration of North American populations of the peregrine falcon (Falco peregrinus). In: DNA Fingerprinting: Approaches and Applications (eds Burke T, Dolf G, Jefferys A, Wolff R), pp. 217229. Birkhauser Press, Brasil, Switzerland.

Meine C, Archibald G (1996) The Cranes: Status Survey and Conservation Action Plan. IUCN - The World Conservation Union, Gland, Switzerland.

Meyer FAA (1794) Zoologische Annalen, 1, 286.

Mills LS, Allendorf FW (1996) The one-migrant-per-generation rule in conservation and management. Conservation Biology, 10, 1509-1518.

Neff BD, Gross MR (2001) Microsatellite evolution in vertebrates: inference from AC dinucleotide repeats. Evolution, 55, 1717-1733.

Nesbitt SA (1975) Spring migration of sandhill cranes from Florida. Wilson Bulletin, 37, 424-426.

Nesbitt SA, Schwikert ST, Folk MJ (2002) Natal dispersal in Florida sandhill cranes. Journal of Wildlife Management, 66, 349-352.

Oberholser HC (1921) Notes on North American birds. X. Auk, 38, 79-82.

Pacific Flyway Council (1983) Pacific Flyway Managment Plan for the Pacific Flyway Population of Lesser Sandhill Cranes. Pacific Flyway Subcommittee. c/o US Fish and Wildlife Service, Portland, Oregon.

Peters JL (1925) Notes on the taxonomy of Ardea canadensis (Linné). Auk, 42, 120-122.

Petersen JL, Bischof R, Krapu GL, Szalanski AL (2003) Genetic variation in the midcontinental population of sandhill cranes, Grus canadensis. Biochemical Genetics, 41, 1-12.

Ploeger PL (1968) Geographical differentiation in arctic Anatidae as a result of isolation during the last glacial. Ardea, 56, 1-155.

Poey F (1854) Apuntes sobre la fauna de la Isla de Pinos. In: Memorias Sobre la Historia Natural de la Isla de Cuba, pp. 424-431. Imprenta de Barcina, Habana, Cuba.

Pogson TH, Lindstedt SM (1991) Distribution and abundance of large sandhill cranes, Grus canadensis, wintering in California central valley. Condor, 93, 266-278.

Pritchard JK, Stephens M, Donnelly P (2000) Inference of population structure using multilocus genotype data. Genetics, 155, 945-959.

Raymond M, Rousset F (1995) GENEPOP (version 1.2): population genetics software for exact tests and ecumenicism. Journal of Heredity, 86, 248-249.

Rhymer JM, Fain MG, Austin JE, Johnson DH, Krajewski C (2001) Mitochondrial phylogeography, subspecific taxonomy, and conservation genetics of sandhill cranes (Grus canadensis; Aves: Gruidae). Conservation Genetics, 2, 203-218.

Rhymer JM, Simberloff D (1996) Extinction by hybridization and introgression. Annual Review of Ecology and Systematics, 27, 83-109.

Rice WR (1989) Analyzing tables of statistical tests. Evolution, 43, 223-225.

Rogers AR (1995) Genetic evidence for a Pleistocene population expansion. Evolution, 49, 608-615.

Schneider S, Roessli D, Excoffier L (2000) ARLEQUIN: software for population genetics data analysis. Version 2.000. Available from http://lgb.unige.ch/arlequin/.
Slatkin M (1985) Rare alleles as indicators of gene flow. Evolution, 39, 53-65.

Stephen WJD (1967) Bionomics of the Sandhill Crane. Canadian Wildlife Service Report Series Number 2, Ottawa, Ontario.

Tacha TC (1981) Behavior and taxonomy of sandhill cranes from midcontinental North America. Dissertation PhD. Oklahoma State University, Stillwater, OK.

Tacha TC (1988) Social organization of sandhill cranes from midcontinental North America. Wildlife Monographs, 99, 1-37.

Tacha TC, Haley DE, George RR (1986) Population and harvest characteristics of sandhill cranes in southern Texas. Journal of Wildlife Management, 50, 80-83.

Tacha TC, Nesbitt SA, Vohs PA (1994) Sandhill crane. In: Migratory Shore and Upland Game Bird Management in North America (eds Tacha TC, Braun CE), pp. 77-94. International Association of Fish and Wildlife Agencies and the US Fish and Wildlife Service, Washington, D.C.

Tacha TC, Vohs PA, Iverson GC (1984) Migration routes of sandhill cranes from mid-continental North America. Journal of Wildlife Management, 48, 1028-1033.

Tacha TC, Vohs PA, Warde WD (1985) Morphometric variation of sandhill cranes from mid-continental North America. Journal of Wildlife Management, 49, 246-250.

Van Wagner CE, Baker AJ (1990) Association between mitochondrialDNA and morphological evolution in Canada geese. Journal of Molecular Evolution, 31, 373-382.

Wahlund S (1928) Zusammensetzung von populationen und Korrelationserscheinungen vom Standpunkt der Vererbungs-lehre ausbetrachtet. Hereditas, 11, 65-106.

Walkinshaw LH (1949) The Sandhill Cranes. Bulletin no. 29. Cranbrook Institute of Science, Bloomfield Hills, Michigan.

Walkinshaw LH (1965) A new sandhill crane from central Canada. Canadian Field Naturalist, 79, 181-184.

Walkinshaw LH (1973) Cranes of the World. Winchester Press, New York.

Webster MS, Marra PP, Haig SM, Bensch S, Holmes RT (2002) Links between worlds: unravelling migratory connectivity. Trends in Ecology \& Evolution, 17, 76-83.

Weir BS, Cockerham CC (1984) Estimating F-statistics for the analysis of population structure. Evolution, 38, 1358-1370.

Wenink PW, Baker AJ, Rosner HU, Tilanus MGJ (1996) Global mitochondrial DNA phylogeography of holarctic breeding dunlins (Calidris alpina). Evolution, 50, 318-330.

Wright S (1978) Evolution and the Genetics of Populations, Variability Within and Among Natural Populations. University of Chicago Press, Chicago, Illinois.

This study was completed as part of Ken Jones's $\mathrm{PhD}$ research on the population studies of several species of cranes, conducted in the Ecology and Evolution Program at the University of Illinois at Chicago, supervised by Mary Ashley. Gary Krapu is a research biologist with the US Geological Survey at the Northern Prairie Wildlife Research Center where he specializes in research addressing ecological requirements of Midcontinental populations of sandhill cranes, waterfowl, and Arctic-nesting sandpipers. David Brandt is a wildlife biologist with the US Geological Survey at the Northern Prairie Wildlife Research Center where he is in charge of field research operations for sandhill crane studies. 